\title{
Methomyl induced gonadal dysfunction, biochemical contents and enzyme activities in male albino mice
}

Manawadi S.I. and Kaliwal B.B. *

P.G. Department of Studies in Biotechnology and Microbiology, Karnatak University, Dharwad, 580003, India, *b_kaliwal@yahoo.com

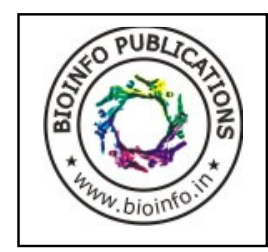

\begin{abstract}
Methomyl (S-methyl-1-N [(methyl carbamoyl) oxy] thio acetimidate, is a carbamate broad spectrum insecticide. The Swiss albino mice were administered orally 1, 2, 3, and $4 \mathrm{mg} / \mathrm{kg}$ body wt methomyl for 30 days and effective dose $4 \mathrm{mg} / \mathrm{kg}$ for 5, 10, and 20 days to know the dose and durational effect on testes and biochemical contents. The mice were sacrificed on day $31^{\text {st }}$ or 24 hours after the terminal exposure. Testes, epididymis, vasa deferentia, seminal vesicles, prostate, coagulatory and Cowper's glands weight decreased significantly with 2,3 and $4 \mathrm{mg} / \mathrm{kg} /$ day and in $4 \mathrm{mg} / \mathrm{kg} /$ day for 10 and 20 days of methomyl treatment.Histologic studies of the testes revealed anti-spermatogenic and anti-steroidogenic effects of methomyl reflected by significant decrease in the number and diameter of spermatogonia, primary spematocytes, secondary spermatocytes, spermatids and Leydig cells in the mice treated with 2,3 and $4 \mathrm{mg} / \mathrm{kg} / \mathrm{day}$ and in $4 \mathrm{mg} / \mathrm{kg} / \mathrm{day}$ for 10 and 20 days of methomyl treatment, except with $2 \mathrm{mg} / \mathrm{kg} /$ day methomyl treatment number of primary spematocytes, Leydig cells, diameter of spermatogonia, and in $4 \mathrm{mg} / \mathrm{kg} /$ day methomyl for 10 days treatment the number of spermatogonia, leydig cells and diameter of primary spermatocytes not changed significantly when compared with controls. Biochemical studies of testis and epididymis showed methomyl at doses of 2, 3 and 4 $\mathrm{mg} / \mathrm{kg} /$ day and in $4 \mathrm{mg} / \mathrm{kg} /$ day for 10 and 20 days of methomyl treatment caused significant decrease in the levels of DNA, RNA, protein, glycogen and sialic acid whereas cholesterol increased significantly. However, treatment with $1,2 \mathrm{mg} / \mathrm{kg} /$ day and $4 \mathrm{mg} / \mathrm{kg} /$ day for 5 days methomyl caused no significant change in epididymal biochemical contents when compared with control. Study on enzyme activities in testis and epididymis revealed that the treatment with 3 and $4 \mathrm{mg} / \mathrm{kg} /$ day and $4 \mathrm{mg} / \mathrm{kg} /$ day for 20 days of methomyl caused significant decrease in the activities of succinic dehydrogenase (SDH), ions ATPase $\left(\mathrm{Na}^{+}-\mathrm{K}^{+} \mathrm{ATPase}, \mathrm{Ca}^{++}\right.$ATPase, $\mathrm{Mg}^{++}$ATPase) and acid phosphatase (ACP) were decreased significantly, except with $3 \mathrm{mg} / \mathrm{kg} /$ day methomyl treatment where $\mathrm{Ca}^{++}$ATPase activity in testes and epididymis not changed significantly. However, lactate dehydrogenase (LDH) and alkaline phosphatase (AKP) activities were increased significantly. The testis $3 \beta$ hydroxysteroid dehydrogenase (3ßHSD) decreased significantly with 3 and $4 \mathrm{mg} / \mathrm{kg} / \mathrm{day}$ and in $4 \mathrm{mg} / \mathrm{kg} / \mathrm{day}$ for 10 and 20 days of methomyl treatment when compared with controls. However, there was no significant change in testes and accessory reproductive organs, number and diameter of spermatogonia and Leydig cells and biochemical contents of testis and epididymis with $1 \mathrm{mg} / \mathrm{kg} / \mathrm{day}$ and in $4 \mathrm{mg} / \mathrm{kg} / \mathrm{day}$ for 5 days of methomyl treatment. These observed effects of methomyl on testes and accessory reproductive organs weight, testis histology, biochemical contents and enzyme activities in testis and epididymis may be due to toxic effect or hormonal imbalance in any of the stage in the hypothalamo-hypophysial-testicular axis.
\end{abstract}

Key words: Methomyl, Testis, Spermatogonia, Leydig cells, Epididymis, Biochemical contents, Enzymes activities, Toxicity.

\section{Introduction}

Methomyl (S-methyl-1-N [(methyl carbamoyl) oxy] thio acetimidate, is a carbamate broad spectrum insecticide. Carbamates quickly paralyze the nervous system of insects by blocking the production and action of cholinesterase thereby known for its rapid knockdown effect [1]. Numerous incidents of acute carbamate poisoning have resulted from inhalation of sprays or contamination of crops or food. Exposure to cholinesterase inhibiting agents is considered a major health problem for the farm workers throughout the world [2]. The active ingredient methomyl containing Lannate is widely using throughout the world since it is effective as "contact insecticide" as well as "systemic insecticide" and is well known established cholinesterase inhibitor. Methomyl has been classified as a pesticide of category-I toxicity [3]. Methomyl is a metabolite of thiodicarb and acetimidate is suspected oncogen which is metabolite in animal tissues [4]. Methomyl is endocrine disruptor and also potent genotoxic, capable of inducing structural and numerical chromosomal aberration in mammalian cells $[5,6]$. Even methomyl induces DNA damage in liver and kidney due to formation of reactive oxygen species (ROS) in mammals [7, 8, 9]. Methomyl intoxicated rats testes revealed variable degrees of degenerative changes in the seminiferous tubules up to total cellular destruction [10]. Reports regarding effect of Lannate on testes are scanty and since biochemical and histological parameters are considered as key points to elucidate toxicity of the chemicals, so the present investigation was undertaken to elucidate the effect of methomyl on testes and biochemical contents of albino mice.

\begin{abstract}
Materials and Methods
Animal

Laboratory bred adult virgin Swiss albino mice were used in the experiments. Mice aged 90 days old weighing between $25-30 \mathrm{~g}$ were used. The mice were maintained in the P.G. Department of Studies in Zoology, Karnatak University, Dharwad. Mice breed quite normally, almost throughout the year and permitted through local ethical committee. They
\end{abstract}


were housed in separate polypropylene cages containing sterile paddy husk as bedding material. The mice were provided with standard mice pellet diet "Gold Mohar" (Hindustan Liver Company, Mumbai) and water ad libitum. The mice were maintained under normal day/night schedule (12 L: $12 \mathrm{D})$ at room temperature $25 \pm 2^{\circ} \mathrm{C}$.

\section{Chemical and Treatment}

The sample of methomyl (Lannate $\AA 40 \%$ SP) used in experiments was commercial insecticide supplied by E.I. Dupont India Pvt. Ltd., Haryana. The doses were given orally in distilled water vehicle at 1,2, 3 and $4 \mathrm{mg} / \mathrm{kg} / \mathrm{d}$ based on daily body weight for 30 days and effective dose $4 \mathrm{mg}$ for 5,10 and 20 days. The doses were given below their acute $L_{50}$ level of intoxication according to their body weight. The mouse oral $L D_{50}$ for methomyl was found to be $10 \mathrm{mg} / \mathrm{kg}$ body weight [3].

\section{Testes and accessory organs}

All the animals were killed on the $31^{\text {st }}$ day after the terminal exposure. The testes, epididymis, vasa deferentia, seminal vesicles, prostate glands, Cowper's glands, coagulatory glands were dissected out. The adherent fatty tissues and blood vessels were removed blotted free of mucous and weighed to the nearest milligram.

\section{Histological studies}

The testes were fixed in Bouin's fluid embedded in paraffin and sectioned at $5 \mu \mathrm{m}$ thickness and stained in haematoxylin-eosin. Sections were examined under the light microscope and general histological appearance was assessed. From each testis 10 sections were randomly selected for histologic and histometric observations were made with a calibrated ocular and stage micrometer. In each section ten seminiferous tubules exhibiting round shape between II to VIII stages were selected in accordance with the criteria given by Leblond and Clermont [11]. The seminiferous tubules were examined for counting the different spermatogenic cells and Leydig cells lying around them. The diameter of spermatogenic cells and Leydig cells were determined after 1000 observations of particular cell types per testis from each animal of control and treated groups. Spermatogonia, primary spermatocytes, secondary spermatocytes, round spermatids and Leydig cells were identified as per findings of earlier investigators [12-15] as reviewed by deKrester and Kerr[16]. The data were expressed as number and diameter of spermatogenic and Leydig cells per seminiferous tubule.

\section{Biochemical estimations}

Freshly removed testes and epididymis were freed from adherent tissues weighed to the nearest milligram and biochemical studies such as estimations of DNA and RNA as per the method of Schnieider [17], protein by Lowry et al., [18], glycogen by Carrol et al., [19], cholesterol by Abell et al. [20], sialic acid by Yao et al. [21], activity of enzymes such as $3 \beta \mathrm{HSD}$ by Shivanandappa and Venkatesh [22], SDH by Nachlas et al., [23], LDH by King [24], $\mathrm{Na}^{+}-\mathrm{K}^{+}$ATPase, $\mathrm{Ca}^{++}$ATPase and $\mathrm{Mg}^{++}$ATPase were assayed according to the method described by Jinna et al., [25], ACP and AKP by Bergmeyer and Bernt [26], in testis and epididymis were carried out.

\section{Statistical analysis}

Statistical significance between the control and experimental data were subjected to analysis of variance (ANOVA) together with Dunnett's test $(\mathrm{P}<0.05)$.

\section{Results}

\section{Testes and accessory sex organs}

Oral administration of the methomyl caused significant decrease in the weight of testes, epididymis, vasa differentia, seminal vesicles, prostate, coagulatory and Cowper's glands weight with 2,3 and $4 \mathrm{mg} / \mathrm{kg} / \mathrm{day}$ and $4 \mathrm{mg} / \mathrm{kg} / \mathrm{day}$ for 10 and 20 days of methomyl treatment. In the mice treated with $1 \mathrm{mg} / \mathrm{kg} /$ day and $4 \mathrm{mg} / \mathrm{kg} /$ day for 5 days of methomyl treatment caused no significant change in testes and accessory organs weight, except with $2 \mathrm{mg} / \mathrm{kg} /$ day and in $4 \mathrm{mg} / \mathrm{kg} /$ day for 10 days of methomyl treatment where the seminal vesicles weight and in $2 \mathrm{mg} / \mathrm{kg} / \mathrm{day}$ coagulatory gland weights where not decreased significantly when compared with controls (Table 1).

\section{Histological studies}

Histological observations of the testis of the control mouse revealed that the seminiferous tubules showed normal spermatogenesis with all cell types and well developed interstitial cells (Fig. 1). Histologic observations of the testis of the mouse treated with $1 \mathrm{mg} / \mathrm{kg} /$ day and $4 \mathrm{mg} / \mathrm{kg} /$ day for 5 days of methomyl showed decrease in the number of spermatocytes, spermatids and sperms in the lumen of seminiferous tubules, interstitial tissue contains clusters of Leydig cells (Fig. 2, 5). Treatment with $1 \mathrm{mg} / \mathrm{kg} /$ day and $4 \mathrm{mg} / \mathrm{kg} /$ day for 5 days of methomyl treatment caused no significant change in number and diameter of spermatogenic and Leydig cells when compared with control. Histological study of the mouse treated with 2 $\mathrm{mg} / \mathrm{kg} / \mathrm{day}$ and $4 \mathrm{mg} / \mathrm{kg} /$ day for 10 days of methomyl exhibits decreased number of spermatogenic cells, formation of vacuoles and less sperms in the lumen of seminiferous tubules. Leydig cells are in deformed conditions (Fig. 3, 6). Treatment with $2 \mathrm{mg} / \mathrm{kg} /$ day and $4 \mathrm{mg} / \mathrm{kg} /$ day for 10 days of methomyl treatment caused significant change in number and diameter of spermatogenic and Leydig cells except in $2 \mathrm{mg} / \mathrm{kg} /$ day methomyl treatment number of primary spematocytes, Leydig cells, diameter of spermatogonia, and in 4 $\mathrm{mg} / \mathrm{kg} /$ day methomyl for 10 days treatment the number of spermatogonia, Leydig cells and diameter of primary spermatocytes not changed significantly when compared with controls. Histologic examination of the testes of the mice treated with 3 and $4 \mathrm{mg} / \mathrm{kg} /$ day and $4 \mathrm{mg} / \mathrm{kg} /$ day for 
20 days of methomyl shows formation of giant cells and lumen with loss of sperms. Leydig cells are in deformed condition, (Fig. 4, 7, 8). Treatment with 3 and $4 \mathrm{mg} / \mathrm{kg} /$ day and $4 \mathrm{mg} / \mathrm{kg} /$ day for 20 days of methomyl also revealed significant decrease in the number and diameter of spermatogonia, primary spematocytes, secondary spermatocytes, spermatids and Leydig cells in the mice treated with 3 and $4 \mathrm{mg} / \mathrm{kg} /$ day and $4 \mathrm{mg} / \mathrm{kg} /$ day for 20 days of methomyl (Table 2).

\section{Biochemical studies}

Biochemical studies of testis and epididymis showed methomyl at doses of 2, 3 and $4 \mathrm{mg} / \mathrm{kg} /$ day and $4 \mathrm{mg} / \mathrm{kg} / \mathrm{day}$ for 10,20 days of treatment caused significant decrease in the levels of DNA, RNA, protein, glycogen and sialic acid where as cholesterol increased significantly, except with 2 $\mathrm{mg} / \mathrm{kg} /$ day methomyl treated groups where the level of DNA was not changed significantly in epididymis and in testes. However, treatment with $1 \mathrm{mg} / \mathrm{kg} /$ day and $4 \mathrm{mg} / \mathrm{kg} /$ day for 5 days of methomyl treatment caused no significant change in biochemical contents of testis as well as in epididymis 1,2 $\mathrm{mg} / \mathrm{kg} / \mathrm{day}$ and $4 \mathrm{mg} / \mathrm{kg} / \mathrm{day}$ for 10 days of methomyl treatment when compared with controls (Table 3, 5).

Study on enzyme activities in testis and epididymis revealed that the treatment with 3 and $4 \mathrm{mg} / \mathrm{kg} / \mathrm{day}$ and $4 \mathrm{mg} / \mathrm{kg} /$ day for 20 days of methomyl treatment resulted in significant decrease in the activities of $\mathrm{SDH}$, ATPases and ACP, except with $3 \mathrm{mg} / \mathrm{kg} / \mathrm{day}$ methomyl where the $\mathrm{Ca}^{++}$ATPase activity was not changed significantly in both organs. However, $\mathrm{LDH}$ and AKP activities were increased significantly. The testis $3 \beta$ hydroxysteroid dehydrogenase (3ßHSD) decreased significantly with 3 and $4 \mathrm{mg} / \mathrm{kg} /$ day and $4 \mathrm{mg} / \mathrm{kg} /$ day for 10,20 days of methomyl treatment. However, treatment with 1 and $2 \mathrm{mg} / \mathrm{kg} /$ day and 4 $\mathrm{mg} / \mathrm{kg} /$ day for 5 , 10 days of methomyl treatment caused no significant change in enzyme activities in testis and epididymis, except the activity of $\mathrm{Na}^{+}-\mathrm{K}^{+}$ ATPase decreased significantly in testis when compared with controls (Table 4, 6).

\section{Discussion}

Testis is a complex organ containing three important cell types such as germ cells, Sertoli cells and Leydig cells in close proximity with unique autonomic and vascular features regulated by endocrine, paracrine and autocrine mechanisms. Spermatogenesis and steroidogenesis are the major functions of testis. It has been stated that the long epididymis provides suitable environment for the spermatozoa to undergo fertilization. The epididymis provides a favorable milieu for the acquisition of fertilizing ability, motility, storage and survival of the spermatozoa [27, 28].

In the present study high dose and prolonged exposure of methomyl cause significant decrease in the weight of the testes and accessory reproductive organs such as epididymis, vasa deferentia, seminal vesicles, prostate, coagulatory and cowper's glands. There are several possible mechanisms for anti-gonadal actions of toxicants. Ferguson et al., [29] have suggested that the treatment with carbamate pesticide carbofuran inhibits acetylcholinesterase (AChe), resulting in alterations in the pituitary gonadotropins and could influence on gonadal function directly through the effect on the pituitary AChe in rats. This may be due to imbalance in gonadal steroids which are essential for normal functioning of the gonads [30]. Carbamates are known to induce oxidative stress in rodents. Reactive oxygen species (ROS) are a double edged sword, they serve as key signal molecules in physiological processes but also have a role in pathological processes involving the reproductive tract. ROS are involved in the peroxidative damage of human spermatozoa, which may result in male infertility [31]. $\mathrm{H}_{2} \mathrm{O}_{2}$ and lipid peroxides are shown to be toxic for spermatozoa [32]. Carter et al., [30] have found that the oral administration of benomyl in the pubertal and post pubertal rats resulted in decrease testicular weight and sperms in the epididymis and vas deferens. The carbamate fungicides, Maneb and Zineb are known to cause testicular atrophy with damaged germinal epithelium and reduced sperm motility and viability $[33,34]$. This may be due to anti-gonadal action of pesticide or deprived levels of androgens, which are very essential for normal functioning of accessory reproductive organs [35]. In rat treated with $17 \mathrm{mg} / \mathrm{kg}$ methomyl for two months caused a significant decrease in the level of testosterone, while the levels of $\mathrm{FSH}, \mathrm{LH}$ and prolactin were significantly increased and histopathological studies of the intoxicated rat testis revealed variable degrees of degenerative changes in the seminiferous tubules up to total cellular destruction [10].

In the present study high dose and prolonged exposure of methomyl caused significant decrease in the number and diameter of spermatogenic cells and Leydig cells, Similarly it has been reported that carbaryl a carbamate insecticide known to cause sperm abnormalities, reduction in number of spermatononia, spermatozoa and degeneration of Leydig cells in rats and mice [36, 37]. Pant et al., [38] have reported carbofuran a carbamate pesticide causes dose dependent reduction in number of epididymal sperm count and sperm motility with increasing abnormal sperms number. It has been observed that members of carbamate pesticides such as disulfiran and its metabolite dithiocarbamate, can interfere with catecholamine neuro transmitter metabolism by inhibiting the activity of dopamine $\beta$-hydroxylase $(\mathrm{D} \beta \mathrm{H})$ this is an enzyme that converts dopamine to norepinephrine and the norepinephorine then stimulates the release of $\mathrm{GnRH}$. Thus $\mathrm{GnRH}$ release is affected through the inhibition of $\mathrm{D} \beta \mathrm{H}[39,40]$. This mechanism plays an important regulatory and/ or modulatory role in brain hypothalamic control of pituitary luteinizing hormone (LH) release [41]. The present investigation gives a clue that high dose and prolonged exposure of methomyl affected spermatogenesis showing anti spermatogenic and anti androgenic property. The effect may be through deprived level of androgens mediated through the gonadotropins of the pituitary due to the effect on hypothalamus $[42,43]$.

In the present study, increasing dose and prolonged exposure of methomyl caused decrease in the level 
of DNA, RNA, protein and glycogen in testes and epididymis of mice. In this concern the mice treated with carbamate insecticide methomyl, carbosulfan and mancozeb inhibited synthesis of DNA, RNA protein and glycogen in kidney, liver and testes respectively $[8,9,44,45]$. It has been reported that the methomyl formulation Lannate ${ }^{\circledR} 25$ induces DNA damage in liver and kidney and induces micronucleus in bone marrow cells of Swiss CDI mice with formulation of reactive oxygen species [7]. In the present study the reason for decreased nucleic acids level on influence of methomyl treatment in mice maybe due to disturbed cell division $[46,47]$ or due to cell damage by increased production of ROS $[48,49,50]$. In the present study increasing dose and prolonged exposure of methomyl caused rise in the cholesterol level in testis and epididymis. This may be due to increased production of ROS which inturn disrupt various enzyme activities. Thus inhibition in the activity of enzymes involved in cholesterol breakup results into deposition of cholesterol into the cell. Carbamate pesticides are known to inhibit hepatic cytochrome p450 enzymes [51], which in turn leads to cholesterol accumulation [8, 9, 44, 45].

Sialic acid is a carbohydrate component attached with protein to form glycoprotein. The sialic acid found at the end of the oligosaccharide chains of many soluble glycoprotein carry a message that determines whether the protein will continue to circulate in the blood stream or be removed by the liver. Sialic acid is concerned with the stabilization of the plasma membrane, maintenance of sperms in a decapitated state, ionic balance in the epididymal plasma and antigen interaction between sperm and epididymal epithelium [52]. The synthesis and/ or secretion of Sialic acid is under androgenic control [53]. The alteration in the Sialic acid level in reproductive tissues indicates change in the level of glycoproteins/FSH and LH needed for normal functioning of gonads and accessory reproductive organs. The $3 \beta$-hydroxysteroid dehydrogenase is a microsomal NAD-dependent enzyme that catalyses the conversion of pregnenolone to progesterone, $17 \alpha$-hydroxypregenolone to 17ahydroxyprogesterone, dehydroepiandrosterone to androstenedione, androstenediol to testosterone [54]. Cytochrome $P_{450}$ aromatase is one which catalyses the conversion of androgens to estrogens [55]. The present study revealed that the increasing dose and prolonged exposure of methomyl caused decrease in the activity of $3 \beta H S D$ in testis. This could be due to inhibition of certain pathways of steroidogenesis by affecting cytochrome $\mathrm{P}_{450}$ [51]. The present data revealed that increase in the dose and prolonged exposure of methomyl caused decrease in the activity of SDH and increase in the LDH activity in mice. Recently Mahagoub and Medany [10] reported that chronic exposure of methomyl (17 mg/ kg body wt) for 2 months revealed significantly decreased $\mathrm{SDH}$ activity in rat testis. In the present study increase in LDH activity indicates leakage of LDH from tissues due to loss of membrane permeability caused by increased oxidative damage $[56,57]$ or by depletion of ATP $[58,59]$. In the present study it has been found that increase in the dose and duration of exposure of methomyl caused decrease in the activity of $\mathrm{Na}^{+}-\mathrm{k}^{+}$ ATPase, $\mathrm{Mg}^{++}$ATPase, and $\mathrm{Ca}^{++}$ATPase in the testes and epididymis. The inhibition of ATPases by pesticides disrupt ATP utilization their by altering the energy metabolism of cells. Methomyl caused significant depletion of ATP in rat muscle and suggested that elevation in LDH and CK and their isoenzymes in serum are due to loss of membrane permeability caused by depletion of ATP [58, 59]. Recently it has been reported that methomyl causes decreased activity of ATPases in liver and kidney in female albino mice [8, 9]. Many authors suggested that $\mathrm{N}$ - methyl carbamates inhibits ATPase system and alters calcium, magnesium homeostasis or energy related metabolic alterations [60, 61]. The effect on ATPase enzyme activity is evidenced by affected spermatogenic cells, decreased testis and accessory organs weight, biochemical contents in albino mice. In the present study, it has been found that prolonged exposure of methomyl caused decrease in the activity of ACP and increase in the activity of AKP in testis and epididymis of albino mice. The activity of ACP and AKP are essential in the formation of ATP. Several studies have been reported that carbamate pesticide such as thiram and mancozeb exposure caused decreased ACP and increased AKP activity in gonads of the rats $[62,63]$. The alteration in the activity of phosphatase enzymes may be due to cellular leakage caused by chemical induced injury of the tissue.

Thus, the results of the present study suggest that chronic exposure to methomyl insecticide has deleterious effect on male mouse reproductive system. Therefore, application of such insecticide for designed program should be limited or special care should be taken to minimize its hazards.

\section{Acknowledgement}

We thank Chairman Post-graduate department of studies in Biotechnology and Microbiology, Karnatak University, Dharwad for providing research facilities.

\section{References}

[1] Pajoumand A., Jalali N., Abdollahi N. and Shadnia S. (2002) J Pharm Pract Res, 32, 297299.

[2] Gianna R., Maria G., Guido M., Roberto B. and Sandra C. (2006) Reproductive Toxicology, 22, 51-55.

[3] Baron R. L. (1991) Carbamate insecticides, In Handbook of Pesticide Toxicology - Vol 3, Hayes WJ., Laws E.R. (Eds). San Diego, Calif, Academic Press, New York. pp 1125-90.

[4] EPA. (1996) Drinking Water Regulations and Health Advisories,USEPA, 822-B-96-002, Washington, $D C$.

[5] Wei L.Y, Chao J.S and Hong C.C. (1997) Environ Mol Mutagen, 29(4), 386-93.

[6] Andersen H. R., Vinggaard A. M., Rasmussen T. $\mathrm{H}$., Gjermandsen I. M. and Bonefeld-Jorgensen E.C. (2002) Toxicol Appl Pharmacol, 179, 1-12. 
[7] Bolognesi C., Peluso M., Degan P., Rabboni R., Munnia A. and Abbondandolo A. (1994) Environ Mol Mutagen, 24(3), 235-242.

[8] Manawadi S. I. and Kaliwal B. B. (2009) Int jrnl of biotech res (suppl), 2(1), 8-16.

[9] Manawadi S. I. and Kaliwal B. B. (2009) Ind. Jrnl of comp Anim physiol, 27(2), 106-112.

[10] Mahgoub A. A. and El-medany A.H. (2001) Pharmac Res, 44(2), 73-80.

[11] Leblond C. P. and Clermont Y. (1952) Ann.NY.Acad.Sci, 55, 548-573.

[12] Oakberg E. F. (1956) Am.J.Anat, 99, 507-516.

[13] Gardner P. (1966) Anat.Res, 155, 235-250.

[14] Dym M. and Fawcett D. W. (1971) Biol.Repro, 4, 195-215.

[15] Fawcett D. W., Neaves W. R. and Flores M. N. (1973) Biol.Reprod, 9, 500-532.

[16] deKrester D. M. and Kerr J. B. (1994) In:Knobil.E., Neil.J.D., (Eds).The physiology of reproduction. Vol.2. Raven Press, New York, pp 1177- 1240

[17] Schneider W.C. (1957) In: Colowick S.P., Kaplan, N.D., (eds) Methods in Enzymology, New York, Academic Press, 680-684.

[18] Lowry H., Rosebrough N.I., Far A.L. and Randall R.J. (1951) J Biol Chem, 193, 265-275.

[19] Carrol N.V., Langely R.W. and Row R.H. (1956) J Biol Chem, 20, 583-593.

[20] Abell L.L., Levy B.B., Brodie B.P. and Kendal F.E. (1952) J Biol Chem, 195, 357-36.

[21] Yao K., Obuka T., Mosuka M., Kinuta M. and Ikeda T. (1989) Analytical Biochemistry, 179, 332-335.

[22] Shivanandappa T. and Venkatesh S. (1997) Anat. Biochem, 254, 57-61.

[23] Nachles M.M., Margulius S.I. and Sellirgman A.M. (1960) J Biol Chem, 235, 2739.

[24] King J. (1965) In: Practical Clinical Enzymology, Edn. Van Z., Norstrand D., Co. London, 83.

[25] Jinna R.R., Ozodinma J.E. and Desaiah D. (1989) J Toxicol Environ Hlth, 27, 199-208.

[26] Bergemeyer H.V. and Bernt E. (1963) In: Methods of enzymatic analysis, (Ed.) HVBergmeyer Acad Press Weinheim, N.Y. and London, 837.

[27] Jehan Q., Setty B.S. and Kar A.B. (1973) Indian J. Expt. Biol, 11, 270.

[28] Brooks D.E. (1981) Physiol. Rev, 61, 515.

[29] Ferguson P.W., Dey M.S., Jewell S.A. and Kriefer R.L. (1984) Toxicol, 4, 14 -21.

[30] Carter S.D., Hein J.F., Rehnburg G.L. and Laskey J.W. (1984) J. Toxicol. Environ. Health, 13, 5368.

[31] Aitken R. J. (1994) Reprod Fertil Dev, 6, 19-24.

[32] Delamirande. E. and Gagnon. C. (1992) J Androl, 13, 368-378.

[33] Sarkar R., Mohan Kumar K.P. and Chowdhury. M. (2000) J. Reprod. Fertil, 118, 29-38.

[34] Lucier G.W., Lee I.P. and Dixon R.L. (1977) In "The testis" Vol-IV. Eds. By Johnson AD, Grames WR, Academic Press, New York. 577.

[35] Rao K. S. and Schwetz B.A. (1982) Ann. Rev. Pub. Health, 3, 1-27.

[36] Shrivastava S.M. and Shrivastava V.K. (1998) Poll Res, 17(3), 215-218.
[37] Raizada R.B., Dutta K.K. and Dikshit T.S. (1979) Bu II Environ Contam Toxicol, 22, 208-213.

[38] Pant N., Prasad A.K., Srivastava S.C., Shankar R.and Srivastava S.P. (1995) Human Expt. Toxicol, 14, 889-894.

[39] Maj J. and Vetulani J. (1969) Biochem. Pharmacol, 18, 2045-2047.

[40] Przewlocka B., Sarnek J., Szmiielski A. and Niewiakomsha A. (1975) Pol. J. Pharmacol. Pharm, 27, 555-559.

[41] Kalra S.P. and Kalra P.S. (1983) Endocr. Rev, 4, 311-351.

[42] Goldman J.M., Parris M.B., Cooper R.L. and McElory W.K. (1997) Reprod.Toxicol, 15, 185190.

[43] Goldman J.M., Stocker J.E., Cooper R.L., McElory W.K. and Hein J.E. (1994) Neuro tox and Teratol, 16, 257-268.

[44] Ksheerasagar R.L. and Kaliwal B.B. (2003) Environ Toxicol Pharmacol, 15, 9-17.

[45] Ksheerasagar R.L. and Kaliwal B.B. (2006) Caspian J Env Sci, 4(1), 61-70.

[46] Topktas M., Rencizogullari E. and lla H.B. (1996) Mutation Res, 371, 259-264

[47] Hemavathy K.C. and Krishnamurthy N.B. (1987) Environ Res, 42 (2), 362-365.

[48] Kim J.G., Sabbagh F., Santanam N., Wilcox J.N., Medford R.M. and Parthasarthy S. (1997) Free Radic Biol Med, 23, 251-259.

[49] Lohitnavy O. and Sinhaseni P. (1998) Arh Hig Rada Toksikol, 49(3), 231-238.

[50] McCarrol N.E., Protzel A., loannou Y., Frank Stack H.F., Jackson M.A., Waters M.D. and Dearfield K.L. (2002) Mutat Res, 512(1), 1-35.

[51] Stott. I., Anupam M., Alex R., Norman W.T. and Jeffrey R.F. (1997) Human Expt Toxicol, 16, 262266.

[52] Rair S.S., Setty B.S. and Kar A.B. (1973) Fertil. Steril, 24, 355

[53] Bohmer T., Weddington S.C. and Hansson V. (1977) Endocrinol, 100, 838.

[54] Darrel W.B., Thomas M.M. and Virendra B.M. (1995) In: Reproductive Toxicology, second edition, edt. Raphael J.W., Raven Press, New York, pp.23-44.

[55] Stoffel-Wagner B. (2001) Eur. J. Endocrinol, 145, 659-679.

[56] Banerjee B.D, Seth V. and Bhattacharya A. (1999) Toxicol Lett, 107: 33-47.

[57] El-Khawaga O.A. (2005) J Physiol Biochem, 61(4), 501-506.

[58] Gupta R.C., Goad J.T. and Kadel W.L. (1994) Neurotoxicity, 15(2), 321-30.

[59] Gupta R.C., Milatovic S., Dettbarn W.D., Aschner M. and Milatoric D. (2007) Toxicol Appl Pharmacol, 219(2-3), 97-105.

[60] Souza dasilva R., Cognato G.P., Vuaden F.C., Rezende M.F., Thiesen F.V., Fauth MdaG., Bogo M.R., Bonan C.D. and Dias R.D. (2003). Comp Biochem Physiol, 135(2), 215-220.

[61] Kamboj A. and Sandhir R. (2007). Neurochem Res, 32(3), 507-16.

[62] Kackar R., Srivastava M.K., Raizada R.B. (1997) Ind. Health, 35, 104-111.

[63] Mishra V.K., Srivastava M.K. and Raizada R.B. (1998) Ind. J. Exptl. Biol, 36(4), 390-394. 

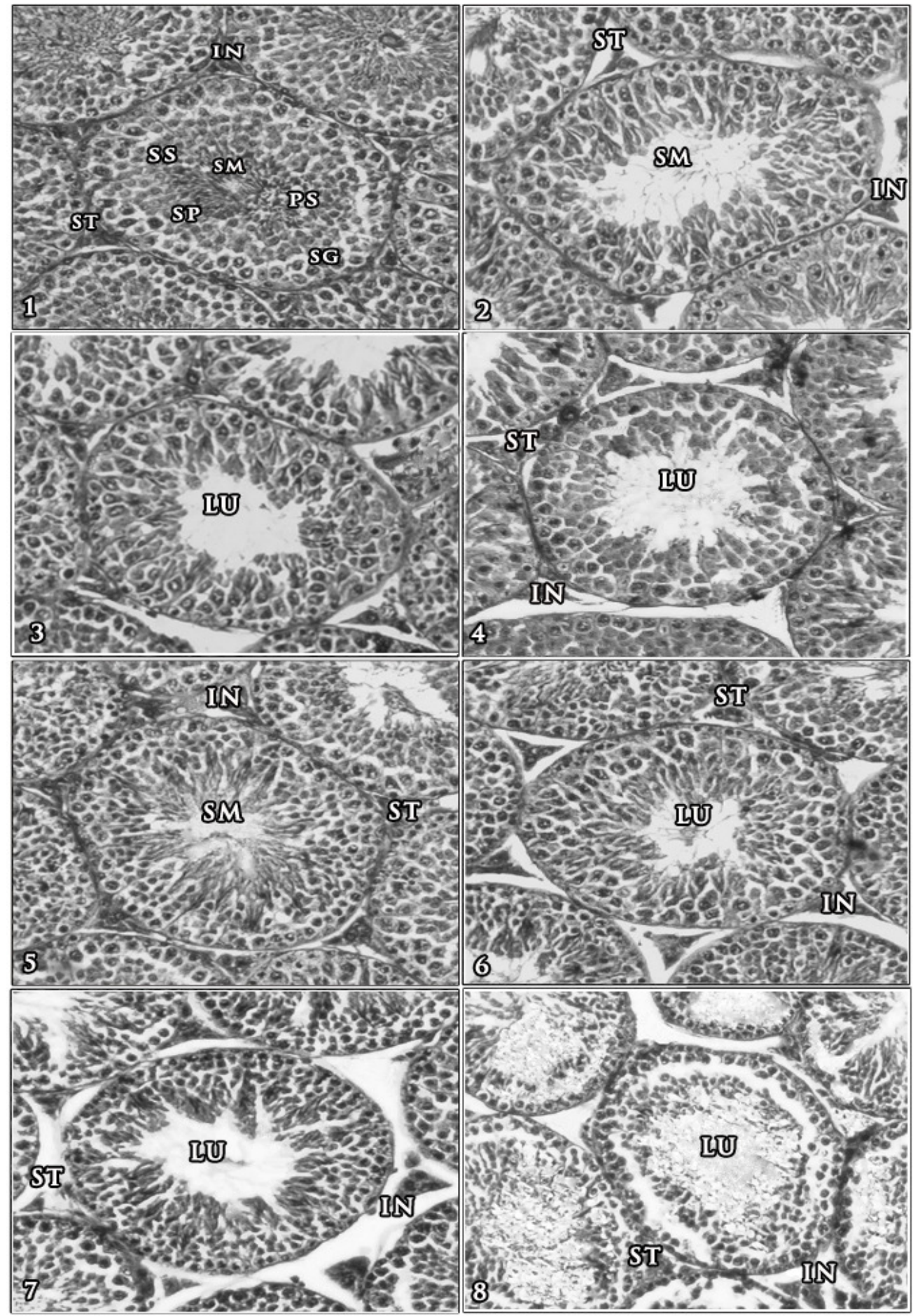
Fig. 1. T.S. of the testis of the control mouse showing different stages of spermatogenesis interstitial tissue contains clusters of Leydig cells H\&E X 200

Fig. 2 .T.S. of the testis of the mouse treated with $1 \mathrm{mg} / \mathrm{kg}$ body weight/ day methomyl showing decreased number of spermatocytes, spermtids and sperms in lumen. H\&E X 200.

Fig. 3.T.S. of the testis of the mouse treated with $2 \mathrm{mg} / \mathrm{kg}$ body weight/ day methomyl showing decreased number of spermatogenic cells as a result of giant cells, vacuoles formation and seminiferous tubular lumen possess less number of sperms. Leydig cells are in deformed condition. H\&E X 200.

Fig. 4 .T.S. of the testis of the mouse treated with $3 \mathrm{mg} / \mathrm{kg}$ body weight / day methomyl showing formation of giant cells and decreased number of spermatogenic cells and lumen with loss of sperms. Leydig cells are in deformed condition. H\&E X 200.

Fig. 5 . T.S. of the testis of the mouse treated with $4 \mathrm{mg} / \mathrm{kg}$ body weight methomyl for 5 days showing abnormal spermatogenesis. The seminiferous tubules are closely packed. The tubular spaces are packed with interstitial tissue, containing clusters of Leydig cells. H\&E X 200.

Fig. 6. T.S. of the testis of the mouse treated with $4 \mathrm{mg} / \mathrm{kg}$ body wt methomyl for 10 days showing different stages of spermatogenesis. Lumen of seminiferuos tubule consists less sperms. Leydig cells are in deformed condition. H\&E X 200.

Fig. 7 . T.S. of the testis of the mouse treated with $4 \mathrm{mg} / \mathrm{kg}$ body wt methomyl for 20 days showing formation of giant cells resulting decreased number of spermatogenic cells and lumen with loss of sperms. H\&E X 200.

Fig. 8 .T.S. of the testis of the mouse treated with $4 \mathrm{mg} / \mathrm{kg}$ body weight/ day methomyl for 30 days showing formation of giant cells, vacuoles and marked reduction in spermatogenic cells. Lumen with tissue debris and clumped sperm fragments. Leydig cells are in deformed condition. H\&E X 200 .

\section{Abbreviations :}
SG -Spermatogonia,
PS-Primary spermatocytes,
SS-Secondary spermtocytes ,
SP-Spermatids ,
SM-Sperms, Lu-Lumen,
ST - Seminiferous tubule,
IN - Interstitial tissue 
Table 1- Effect on weights of testes and accessory reproductive organs in albino mice after exposure to Methomyl

\begin{tabular}{|c|c|c|c|c|c|c|c|}
\hline \multirow[t]{2}{*}{ Treatment } & \multicolumn{7}{|c|}{ Relative organs weight (mg / 100 g body weight) } \\
\hline & Testes & Epididymis & Vasa deferentia & Seminal vesicles & Prostate gland & $\begin{array}{c}\text { Coagulatory } \\
\text { gland }\end{array}$ & Cowpers glands \\
\hline Control & $745.6 \pm 0.92$ & $333.4 \pm 0.54$ & $190.9 \pm 0.35$ & $803.0 \pm 0.47$ & $95.6 \pm 0.26$ & $175.4 \pm 0.56$ & $155.0 \pm 0.62$ \\
\hline $1 \mathrm{mg} / \mathrm{kg} / \mathrm{d}$ & $742.8 \pm 0.44$ & $331.6 \pm 0.43$ & $189.5 \pm 0.47$ & $802.6 \pm 0.34$ & $94.9 \pm 0.23$ & $172.8 \pm 0.72$ & $153.7 \pm 0.57$ \\
\hline $2 \mathrm{mg} / \mathrm{kg} / \mathrm{d}$ & $700.5 \pm 0.94^{*}$ & $327.5 \pm 0.60^{*}$ & $188.8 \pm 0.34^{*}$ & $801.9 \pm 0.35$ & $94.0 \pm 0.21$ & $171.1 \pm 0.70$ & $153.0 \pm 0.56^{*}$ \\
\hline $3 \mathrm{mg} / \mathrm{kg} / \mathrm{d}$ & $659.7 \pm 0.97^{*}$ & $317.5 \pm 0.45^{*}$ & $162.0 \pm 0.42^{*}$ & $750.5 \pm 0.56^{*}$ & $83.9 \pm 0.46^{*}$ & $161.3 \pm 1.10^{*}$ & $145.9 \pm 0.34^{*}$ \\
\hline $4 \mathrm{mg} / \mathrm{kg} / \mathrm{d}$ & $630.5 \pm 0.74^{*}$ & $299.3 \pm 0.58^{*}$ & $158.6 \pm 0.43^{*}$ & $710.5 \pm 1.82^{*}$ & $77.5 \pm 0.34^{*}$ & $154.6 \pm 1.02^{*}$ & $139.0 \pm 0.33^{*}$ \\
\hline 5 days & $743.7 \pm 0.57$ & $338.0 \pm 0.45$ & $189.8 \pm 0.45$ & $802.0 \pm 0.47$ & $95.0 \pm 0.21$ & $173.0 \pm 0.68$ & $154.0 \pm 0.63$ \\
\hline 10 days & $700.9 \pm 0.80^{*}$ & $324.2 \pm 0.67^{\star}$ & $180.9 \pm 0.36^{*}$ & $801.7 \pm 0.33$ & $94.2 \pm 0.20^{*}$ & $169.8 \pm 0.78^{*}$ & $150.3 \pm 0.50^{*}$ \\
\hline 20 days & $659.7 \pm 0.86^{*}$ & $308.5 \pm 0.54^{*}$ & $162.3 \pm 0.52^{*}$ & $751.8 \pm 0.84^{*}$ & $85.2 \pm 0.51^{*}$ & $161.7 \pm 0.88^{*}$ & $146.3 \pm 0.40^{*}$ \\
\hline
\end{tabular}


Table 2- Effect on number and diameter of spermatogenic and Leydig cells in albino mice after exposure to methomyl

\begin{tabular}{|c|c|c|c|c|c|c|c|c|c|c|}
\hline \multirow[t]{2}{*}{ Treatment } & \multicolumn{5}{|c|}{ Number of spermatogenic and Leydig cells } & \multicolumn{5}{|c|}{ Diameter $(\mu \mathrm{m})$ of spermatogenic and Leydig cells } \\
\hline & $\begin{array}{l}\text { Sperma- } \\
\text { togonia }\end{array}$ & $\begin{array}{l}\text { Primary } \\
\text { sperma- } \\
\text { tocytes }\end{array}$ & $\begin{array}{c}\text { Secondary } \\
\text { sperma- } \\
\text { tocytes }\end{array}$ & Spermatids & Leydig cells & $\begin{array}{c}\text { Sperma- } \\
\text { togonia }\end{array}$ & $\begin{array}{l}\text { Primary } \\
\text { sperma- } \\
\text { tocytes }\end{array}$ & $\begin{array}{c}\text { Secondary } \\
\text { spermatocyte } \\
\text { s }\end{array}$ & $\underset{\mathbf{S}}{\text { Spermatid }}$ & Leydig cells \\
\hline Control & $67.9 \pm 0.18$ & $92.1 \pm 0.18$ & $100.6 \pm 0.34$ & $168.1 \pm 0.58$ & $44.4 \pm 0.26$ & $8.0 \pm 0.21$ & $9.3 \pm 0.15$ & $7.7 \pm 0.15$ & $6.3 \pm 0.15$ & $9.6 \pm 0.16$ \\
\hline $1 \mathrm{mg} / \mathrm{kg} / \mathrm{d}$ & $67.2 \pm 0.25$ & $91.6 \pm 0.26$ & $99.7 \pm 0.21$ & $167.1 \pm 0.43$ & $43.4 \pm 0.27$ & $7.6 \pm 0.16$ & $9.0 \pm 0.15$ & $7.4 \pm 0.16$ & $6.1 \pm 0.10$ & $9.3 \pm 0.15$ \\
\hline $2 \mathrm{mg} / \mathrm{kg} / \mathrm{d}$ & $64.1 \pm 0.18^{*}$ & $91.1 \pm 0.27$ & $99.2 \pm 0.36$ * & $164.7 \pm 0.39^{*}$ & $42.6 \pm 0.22$ & $7.3 \pm 0.26$ & $8.4 \pm 0.16^{*}$ & $7.1 \pm 0.10^{*}$ & $5.8 \pm 0.13^{*}$ & $8.7 \pm 0.15^{*}$ \\
\hline $3 \mathrm{mg} / \mathrm{kg} / \mathrm{d}$ & $62.2 \pm 0.20^{*}$ & $87.6 \pm 0.16^{*}$ & $94.6 \pm 0.16$ * & $162.9 \pm 0.50$ * & $38.9 \pm 1.00^{*}$ & $6.4 \pm 0.16^{\star}$ & $7.3 \pm 0.15^{*}$ & $6.7 \pm 0.15^{*}$ & $5.0 \pm 0.04^{*}$ & $7.5 \pm 0.16^{*}$ \\
\hline $4 \mathrm{mg} / \mathrm{kg} / \mathrm{d}$ & $59.4 \pm 0.16^{*}$ & $85.6 \pm 0.16^{*}$ & $92.4 \pm 0.34$ * & $161.3 \pm 0.15^{*}$ & $38.3 \pm 0.30^{*}$ & $6.1 \pm 0.18^{*}$ & $7.1 \pm 0.18^{*}$ & $6.3 \pm 0.22$ * & $4.9 \pm 0.10^{*}$ & $6.4 \pm 0.16^{*}$ \\
\hline 5 days & $67.3 \pm 0.26$ & $91.7 \pm 0.20$ & $99.9 \pm 0.23$ & $167.4 \pm 0.42$ & $43.8 \pm 0.29$ & $7.4 \pm 0.16$ & $9.0 \pm 0.15$ & $7.3 \pm 0.15$ & $6.0 \pm 0.14$ & $9.1 \pm 0.10$ \\
\hline 10 days & $66.5 \pm 0.45$ & $89.2 \pm 0.44^{*}$ & $99.0 \pm 0.29^{*}$ & $165.00 \pm 0.42^{*}$ & $42.9 \pm 0.18$ & $6.6 \pm 0.16^{*}$ & $8.8 \pm 0.13$ & $6.8 \pm 0.13^{*}$ & $5.4 \pm 0.16^{*}$ & $8.5 \pm 0.22$ * \\
\hline 20 days & $62.4 \pm 0.26^{*}$ & $86.9 \pm 0.23^{*}$ & $94.3 \pm 0.21^{*}$ & $163.2 \pm 0.5^{*}$ & $39.2 \pm 0.45^{\star}$ & $6.3 \pm 0.21^{*}$ & $7.6 \pm 0.16^{*}$ & $6.7 \pm 0.15^{\star}$ & $5.1 \pm 0.10^{*}$ & $7.3 \pm 0.15^{*}$ \\
\hline
\end{tabular}


Table 3- Effect on biochemical contents of testis in albino mice after exposure to methomyl

\begin{tabular}{|c|c|c|c|c|c|c|}
\hline \multirow[t]{2}{*}{ Treatment } & \multicolumn{6}{|c|}{ Biochemical contents ( $\mu \mathrm{g} / \mathrm{mg}$ wet weight of tissue) } \\
\hline & DNA & RNA & Protein & Glycogen & Cholesterol & Sialic acid \\
\hline Control & $2.51 \pm 0.03$ & $4.68 \pm 0.02$ & $147.7 \pm 0.15$ & $6.52 \pm 0.02$ & $9.25 \pm 0.02$ & $15.6 \pm 0.16$ \\
\hline $1 \mathrm{mg} / \mathrm{kg} / \mathrm{d}$ & $2.46 \pm 0.02$ & $4.62 \pm 0.03$ & $147.1 \pm 0.27$ & $6.48 \pm 0.03$ & $9.3 \pm 0.01$ & $15.1 \pm 0.18$ \\
\hline $2 \mathrm{mg} / \mathrm{kg} / \mathrm{d}$ & $2.44 \pm 0.03$ & $4.58 \pm 0.02^{*}$ & $146.4 \pm 0.22^{*}$ & $6.43 \pm 0.02$ * & $9.42 \pm 0.02^{*}$ & $14.8 \pm 0.20^{*}$ \\
\hline $3 \mathrm{mg} / \mathrm{kg} / \mathrm{d}$ & $2.33 \pm 0.02^{*}$ & $4.13 \pm 0.03^{*}$ & $140.5 \pm 0.26$ * & $6.15 \pm 0.02^{*}$ & $9.62 \pm 0.01^{*}$ & $13.6 \pm 0.22^{*}$ \\
\hline $4 \mathrm{mg} / \mathrm{kg} / \mathrm{d}$ & $2.11 \pm 0.02^{*}$ & $3.87 \pm 0.01^{*}$ & $135.5 \pm 0.37$ * & $5.53 \pm 0.02$ * & $9.81 \pm 0.01^{*}$ & $12.5 \pm 0.16^{*}$ \\
\hline 5 days & $2.48 \pm 0.03$ & $4.64 \pm 0.02$ & $147.3 \pm 0.21$ & $6.45 \pm 0.03$ & $9.33 \pm 0.02$ & $15.0 \pm 0.21$ \\
\hline 10 days & $2.42 \pm 0.03$ & $4.60 \pm 0.03$ & $146.8 \pm 0.25^{\star}$ & $6.41 \pm 0.03^{*}$ & $9.45 \pm 0.02^{*}$ & $14.3 \pm 0.21^{*}$ \\
\hline 20 days & $2.29 \pm 0.02^{*}$ & $4.13 \pm 0.03^{*}$ & $141.2 \pm 0.29^{*}$ & $6.19 \pm 0.02^{*}$ & $9.65 \pm 0.01^{*}$ & $13.3 \pm 0.15^{\star}$ \\
\hline
\end{tabular}


Table 4- Effect on testis dehydrogenase and phosphatase enzymes activity in albino mice after exposure to methomyl

\begin{tabular}{|c|c|c|c|c|c|c|c|c|}
\hline \multirow[t]{2}{*}{ Treatment } & \multicolumn{8}{|c|}{ Enzyme activity ( $\mu \mathrm{moles} / \mathrm{min} / \mathrm{g}$ tissue weight) } \\
\hline & $\mathrm{LDH}^{\mathrm{a}}$ & SDH $^{\circ}$ & $3 \beta H_{S D}{ }^{c}$ & $\mathrm{Na}^{+}-\mathrm{K}^{+} \mathrm{ATPase} \mathrm{a}^{\mathrm{a}}$ & Mg $^{++}$ATPase $^{\alpha}$ & Ca $^{++}$ATPase $^{a}$ & $\mathbf{A C P}^{\mathrm{e}}$ & $\mathbf{A K P}^{\mathrm{e}}$ \\
\hline Control & $9.06 \pm 0.02$ & $12.20 \pm 0.20$ & $0.44 \pm 0.01$ & $7.45 \pm 0.02$ & $9.00 \pm 0.04$ & $6.10 \pm 0.03$ & $18.80 \pm 0.30$ & $14.10 \pm 0.18$ \\
\hline $1 \mathrm{mg} / \mathrm{kg} / \mathrm{d}$ & $9.10 \pm 0.02$ & $12.15 \pm 0.24$ & $0.43 \pm 0.02$ & $7.42 \pm 0.01$ & $8.96 \pm 0.03$ & $6.08 \pm 0.01$ & $18.60 \pm 0.24$ & $14.05 \pm 0.10$ \\
\hline $2 \mathrm{mg} / \mathrm{kg} / \mathrm{d}$ & $9.11 \pm 0.01$ & $12.09 \pm 0.20$ & $0.41 \pm 0.01$ & $7.38 \pm 0.03$ & $8.90 \pm 0.02$ & $6.07 \pm 0.01$ & $18.50 \pm 0.42$ & $14.00 \pm 0.12$ \\
\hline $3 \mathrm{mg} / \mathrm{kg} / \mathrm{d}$ & $10.08 \pm 0.01^{*}$ & $11.60 \pm 0.22^{*}$ & $0.37 \pm 0.01^{*}$ & $7.00 \pm 0.04^{*}$ & $7.80 \pm 0.01^{*}$ & $6.05 \pm 0.01$ & $17.60 \pm 0.30^{*}$ & $14.90 \pm 0.10^{*}$ \\
\hline $4 \mathrm{mg} / \mathrm{kg} / \mathrm{d}$ & $10.30 \pm 0.02^{*}$ & $11.15 \pm 0.10^{*}$ & $0.32 \pm 0.01^{*}$ & $6.42 \pm 0.02^{*}$ & $7.10 \pm 0.02^{*}$ & $5.42 \pm 0.02^{*}$ & $16.20 \pm 0.20^{*}$ & $15.50 \pm 0.24^{*}$ \\
\hline 5 days & $9.08 \pm 0.02$ & $12.12 \pm 0.18$ & $0.42 \pm 0.02$ & $7.43 \pm 0.01$ & $8.94 \pm 0.02$ & $6.07 \pm 0.01$ & $18.70 \pm 0.24$ & $14.12 \pm 0.10$ \\
\hline 10 days & $9.10 \pm 0.04$ & $12.10 \pm 0.22$ & $0.37 \pm 0.02^{\star}$ & $7.32 \pm 0.03^{\star}$ & $8.90 \pm 0.03$ & $6.04 \pm 0.01$ & $18.65 \pm 0.20$ & $14.14 \pm 0.12$ \\
\hline 20 days & $10.14 \pm 0.01^{*}$ & $11.40 \pm 0.22^{*}$ & $0.35 \pm 0.02^{*}$ & $7.10 \pm 0.04^{*}$ & $7.75 \pm 0.02^{*}$ & $5.80 \pm 0.02^{*}$ & $17.70 \pm 0.32^{*}$ & $14.90 \pm 0.12^{*}$ \\
\hline
\end{tabular}

a $\mu$ moles of pyruvate formed $/ \mathrm{min} / \mathrm{g}$ tissue

c $\mu$ moles of NAD converted to $\mathrm{NADH} / \mathrm{min} / \mathrm{g}$ tissue

d $\mu$ moles of inorganic phosphorus formed $/ \mathrm{min} / \mathrm{g}$ tissue.

e $\mu$ moles of P-nitrophenyl formed/ min/g tissue

Values are mean \pm SEM of 5 animals ${ }^{*}$ Significant $P \leq 0.05$ compared with control 
Table 5- Effect on biochemical contents of epididymis in albino mice after exposure to methomyl

\begin{tabular}{|c|c|c|c|c|c|c|}
\hline \multirow[t]{2}{*}{ Treatment } & \multicolumn{6}{|c|}{ Biochemical contents ( $\mu \mathrm{g} / \mathrm{mg}$ wet weight of tissue) } \\
\hline & DNA & RNA & Protein & Glycogen & Cholesterol & Sialic acid \\
\hline Control & $2.40 \pm 0.03$ & $4.52 \pm 0.02$ & $220.20 \pm 0.22$ & $7.40 \pm 0.16$ & $8.40 \pm 0.02$ & $12.20 \pm 0.42$ \\
\hline $1 \mathrm{mg} / \mathrm{kg} / \mathrm{d}$ & $2.38 \pm 0.02$ & $4.50 \pm 0.04$ & $216.20 \pm 0.16$ & $7.36 \pm 0.10$ & $8.45 \pm 0.04$ & $12.14 \pm 0.32$ \\
\hline $2 \mathrm{mg} / \mathrm{kg} / \mathrm{d}$ & $2.35 \pm 0.02$ & $4.40 \pm 0.02$ & $210.3 \pm 0.24$ & $7.30 \pm 0.12$ & $8.52 \pm 0.02$ & $12.10 \pm 0.20$ \\
\hline $3 \mathrm{mg} / \mathrm{kg} / \mathrm{d}$ & $2.34 \pm 0.01^{*}$ & $4.10 \pm 0.03^{*}$ & $198.4 \pm 0.48^{*}$ & $6.64 \pm 0.10^{*}$ & $9.68 \pm 0.04^{*}$ & $11.40 \pm 0.32^{*}$ \\
\hline $4 \mathrm{mg} / \mathrm{kg} / \mathrm{d}$ & $2.10 \pm 0.01^{*}$ & $4.00 \pm 0.02^{\star}$ & $190.1 \pm 0.30^{*}$ & $6.60 \pm 0.12^{*}$ & $9.90 \pm 0.04^{*}$ & $11.12 \pm 0.20^{*}$ \\
\hline 5 days & $2.38 \pm 0.01$ & $4.48 \pm 0.02$ & $215.6 \pm 0.14$ & $7.34 \pm 0.08$ & $8.44 \pm 0.03$ & $12.15 \pm 0.22$ \\
\hline 10 days & $2.36 \pm 0.03$ & $4.42 \pm 0.03$ & $211.2 \pm 0.20$ & $7.28 \pm 0.12$ & $8.50 \pm 0.04$ & $12.12 \pm 0.24$ \\
\hline 20 days & $2.30 \pm 0.02^{*}$ & $4.08 \pm 0.02^{*}$ & $199.2 \pm 0.28^{*}$ & $6.68 \pm 0.14^{*}$ & $9.60 \pm 0.05^{\star}$ & $11.40 \pm 0.30^{*}$ \\
\hline
\end{tabular}


Table 6- Effect on epididymis dehydrogenase and phosphatase enzymes activity in albino mice after exposure to methomyl

\begin{tabular}{|c|c|c|c|c|c|c|c|}
\hline \multirow[t]{2}{*}{ Treatment } & \multicolumn{7}{|c|}{ Enzyme activity ( $\mu$ moles / $\mathrm{min} / \mathrm{g}$ tissue weight) } \\
\hline & LDH $^{\mathbf{a}}$ & SDH $^{\mathrm{b}}$ & $\mathrm{Na}^{+}-\mathrm{K}^{+} \mathrm{ATPase} \mathrm{c}^{\mathrm{C}}$ & Mg $^{++}$ATPase $^{c}$ & Ca $^{++}$ATPase $^{c}$ & $\mathbf{A C P}^{\mathrm{d}}$ & $\mathbf{A K P}^{\mathrm{d}}$ \\
\hline Control & $15.20 \pm 0.18$ & $14.12 \pm 0.22$ & $8.62 \pm 0.15$ & $10.70 \pm 0.51$ & $6.70 \pm 0.10$ & $15.40 \pm 0.22$ & $13.60 \pm 0.40$ \\
\hline $1 \mathrm{mg} / \mathrm{kg} / \mathrm{d}$ & $15.16 \pm 0.24$ & $14.08 \pm 0.16$ & $8.55 \pm 0.28$ & $10.62 \pm 0.44$ & $6.65 \pm 0.24$ & $15.30 \pm 0.16$ & $13.66 \pm 0.16$ \\
\hline $2 \mathrm{mg} / \mathrm{kg} / \mathrm{d}$ & $15.12 \pm 0.30$ & $13.98 \pm 0.10$ & $8.45 \pm 0.30$ & $10.54 \pm 0.45$ & $6.62 \pm 0.30$ & $15.26 \pm 0.28$ & $13.94 \pm 0.26$ \\
\hline $3 \mathrm{mg} / \mathrm{kg} / \mathrm{d}$ & $16.00 \pm 0.20^{*}$ & $13.10 \pm 0.34^{*}$ & $7.56 \pm 0.30^{*}$ & $9.76 \pm 0.24^{*}$ & $6.56 \pm 0.38$ & $14.65 \pm 0.20^{*}$ & $14.80 \pm 0.12^{*}$ \\
\hline $4 \mathrm{mg} / \mathrm{kg} / \mathrm{d}$ & $16.70 \pm 0.36^{*}$ & $12.84 \pm 0.42^{*}$ & $7.10 \pm 0.12^{*}$ & $9.51 \pm 0.21^{*}$ & $5.96 \pm 0.26^{*}$ & $14.32 \pm 0.24^{*}$ & $15.36 \pm 0.20$ * \\
\hline 5 days & $15.14 \pm 0.20$ & $14.09 \pm 0.26$ & $8.58 \pm 0.14$ & $10.65 \pm 0.40$ & $6.62 \pm 0.14$ & $15.34 \pm 0.18$ & $13.62 \pm 0.12$ \\
\hline 10 days & $15.10 \pm 0.26$ & $13.95 \pm 0.14$ & $8.50 \pm 0.20$ & $10.60 \pm 0.35$ & $6.60 \pm 0.32$ & $15.29 \pm 0.24$ & $13.88 \pm 0.28$ \\
\hline 20 days & $16.00 \pm 0.40^{*}$ & $13.20 \pm 0.24^{*}$ & $7.50 \pm 0.32^{*}$ & $9.96 \pm 0.14^{*}$ & $6.16 \pm 0.25^{*}$ & $14.60 \pm 0.10^{*}$ & $14.70 \pm 0.28^{*}$ \\
\hline $\begin{array}{lr}\mathrm{a} & \mu \text { moles o } \\
\mathrm{b} & \mu \text { moles o } \\
\mathrm{c} & \mu \text { moles o } \\
\mathrm{d} & \mu \text { moles o } \\
\mathrm{e} & \mu \text { moles o } \\
\text { Values are me }\end{array}$ & $\begin{array}{l}\text { uvate formed/ } \\
\text { nazon formed/ } \\
\text { D converted to } \\
\text { rganic phospho } \\
\text { itrophenyl form }\end{array}$ & $\begin{array}{l}\mathrm{g} \text { tissue } \\
\mathrm{g} \text { tissue } \\
\mathrm{H} / \mathrm{min} / \mathrm{g} \text { tissue } \\
\text { ormed/ } \mathrm{min} / \mathrm{g} \text { ti } \\
\mathrm{nin} / \mathrm{g} \text { tissue }\end{array}$ & & & & & \\
\hline
\end{tabular}

